Journal of Economics and Behavioral Studies (ISSN: 2220-6140)

Vol. 8, No. 1, pp. 50-57, February 2016

\title{
Performance of High School Students in Vhembe District
}

\author{
Kwabena A. Kyei, T. Maboko \\ University of Venda, Thohoyandou, Limpopo Province, South Africa \\ Kyei61@gmail.com
}

\begin{abstract}
Despite the attempts by South African government to make education accessible to all by introducing free food and free textbooks at the primary school level, there is still high failure rate in mathematics and science in high schools in the country. This study makes attempt to establish some factors that affect the performance of students, especially in science subjects in high schools in the Vhembe district in the Limpopo province. A survey was conducted in 17 high schools randomly sampled in the Vhembe district. Purposive sampling was used to get the grade 11 and 12 students and their teachers. About 700 students, 70 teachers and 17 principals were interviewed. The study concludes that the overall pass rate is $70 \%$ but the rate in mathematics and science is hardly 40\%; and the key factors affecting performance are lack of laboratory for practical, awards, shuffling and textbooks. The study recommends that science laboratories be built in schools, textbooks be supplied in good time and teachers to motivate students by giving awards.
\end{abstract}

\section{Keywords: Shuffling, laboratory, textbooks, awards, educational environment}

\section{Introduction}

Poor performance of students in high and higher institutions in South Africa comes from many dimensions unqualified staff, staff members who are neither committed nor regular at school and a host of them. High schools are meant to prepare students (learners) for colleges or tertiary institutions which have the clear duty internationally, to build the right set of knowledge, skills and attitudes that will increase the employability of students. Good academic performance in high school is therefore crucial and that requires a positive school environment for students to feel comfortable in school, much as at home. Education and skills development promote individual, social and economic development. High quality education and appropriate competences and capabilities are prerequisites for growth, development and citizenship, which in turn can afford more people the opportunity to learn to enhance their capabilities and to contribute to a productive society (McGrath, 2010: 2). For decades and even now a lot of constraints have hampered academic performance at high school level in South Africa. Unqualified teachers, shortage of staff, inadequate resources, teenage pregnancies and lack of support and mentorship, have all contributed to the poor performance of students in high schools. Education and training during the old regime in South Africa was characterised by the underdevelopment of human potential, especially among the blacks. The teaching and learning of Mathematics and the Sciences, in particular, were affected the most. For example, the Third International Mathematics and Science Study conducted in 1995, in which South Africa participated with 41 others, reported that South Africa students came last with a score of 351 (Mji and Makgato, 2006: 253). In 2013, they again came last with a score of 380. Post-apartheid African National Congress government has repeatedly said that they have come to redress the inequality that existed during the apartheid regime. They came with a formula which states, among other things, that the poorest $40 \%$ of schools should receive $60 \%$ provincial schooling non-personnel budget allocation; and the less poor $20 \%$ of schools are to receive $5 \%$ of the resources (National Maintenance Act, (NNSSF Act), 1998). The question now is: has this formula been able to redress the poor performance of the rural students in Vhembe? This paper examines the performance of grade 12 (form five students in high schools) in the Vhembe district and, determines factors affecting performance and recommends measures needed to turn the negative results around.

\section{Literature Review}

Although there are substantial global efforts to increase and improve the scientific literacy in the country, it has however been recently realized that the science education systems are turning out less science graduates at all levels than the global economy requires (Muwanga-Zake, 2008: 1, Muzah, 2011: 112; Cameron, 
2009:15-16; Einhorn, 2008: 2). There has been a decline in science graduates all over the world and that has contributed to failure rate in schools (Fonseca and Conboy, 2006:82; Madibeng, 2006:1-2).The most common problem linked to students' poor performance in science in most developed countries is mainly shortage of qualified and experienced science teachers (Ruby, 2006: 1007). In contrast, most developing countries, including South Africa, have a host of factors ranging from lack of adequate science resources and facilities such as apparatus and laboratories, shortage of trained and qualified science educators, large science classes, limited proficiency in medium of instruction to outdated teaching methods (Howe, 2003: 1-2; Makgato, 2007: 90; Mji and Makgato, 2006:259-261; Muwanga-Zake, 2008: 4-6). Studies have associated shortage of qualified teachers with lack of thorough preparation for lessons and reduced coverage of content (Muzah, 2011: 109).

Education researchers in South Africa agree that there are acute shortages of teachers, especially in Sciences and Mathematics. Many institutions in the country lack infrastructural facilities that promote healthy learning (Ardens, 2010: 1-3).There are several studies locally and internationally regarding poor performance at high school level. These studies revealed that in many cases the level of academic performance in urban and rural areas is not the same, and that the urban students tend to perform better than those in the rural areas (Saiduddin, 2003: 22; Themane, 1989: 151; Munn, 1996:44). However, Kyei and Nemaorani (2014) found out that the performance of grade 10 (form three students) in rural areas in the Vhembe district is rather better than in urban areas; the reason they attributed to lack of entertainment/social centres in rural areas to attract and distract students from their studies. According to Muzah (2011:54), the views and opinions of educators and learners showed that the main causes of high failure rates are poor teachers' qualifications, outdated teaching methods, massive workloads, high levels of absenteeism and acute deficiencies in aspects related to: resources, subjects content, classroom management skills, proficiency in language of instruction and assessment, motivation and perseverance as well as poverty.

The UN convention on the Rights of the Child states that every child has the right to an education that develops their personality, talents, mental and physical abilities to their fullest potential (www: unicef.org/southafrica). And every school's mission should be the education of students to become knowledgeable, responsible, socially skilled, healthy, caring and contributing citizens (www: unicef.org/southafrica).Though there are increasing levels of female school participation in South Africa as elsewhere in sub-Saharan Africa, a great number of young female students become pregnant, perform poorly or fall out of school; and the (pregnancy) prevalent rate in South Africa is shocking (Grant and Hallman, 2006:12). The high failure rate in Mathematics and Science in South Africa continues to be very disturbing and creates concerns, especially in historically disadvantaged townships and rural public high schools. Underachievement in Science and Mathematics in these schools is skyrocketing in an era when the ability to apply science is spreading out at an exponential rate to the daily lives and worldwide events (Muzah, 2011:91). Maybe the underlying reasons for under-achievement of students in science at final year (matriculation) level, particularly in historically disadvantaged public high schools of South Africa, have not yet been sufficiently researched or appropriately treated.

\section{Methodology}

Material/Data: A survey was conducted within seventeen high schools randomly sampled in the Vhembe district. The principals, teachers (educators) teaching science subjects and students in grades $11 \& 12$ (forms $4 \& 5$ ) were purposively selected from the sampled schools and interviewed. About 700 students, 70 teachers and 17 principals were involved. Some of the questions in the questionnaire were the following: Does class size affect academic performance? Do you do Physics practical in your school? Do you do Life-Science practical in your school? Do you have a textbook for each subject that you are taught? Are you shuffled in your school/classes? And do you get Awards if you have performed well academically?

Analysis: The analytical tools employed for this study include a logit model and multiple regressions. A logit model is a useful measure to study the relationship between a binary response variable and one or more explanatory variable(s). Multiple regression modelling provides an elegant method of describing a relationship between a response variable and predictors. The models provide improved precision for estimation and prediction by using a linear surface such as a plane or hyper plane to approximate the relationship between a continuous response variable and a set of predictor variables (which may be continuous or categorical) (Larose, 2006: 93-99). 


\section{Results}

Table 1: Basic statistical analysis (Univariate Analysis)

\begin{tabular}{lll}
\hline Variable & Frequency & Percentage \\
\hline Does class size affect academic performance? & \\
No & 350 & 53.0 \\
Yes & 311 & 47.0 \\
Do you do Physics practical in you school? & \\
No & 226 & 38.8 \\
Yes & 357 & 61.2 \\
Do you do Life-Science practical in your school? & \\
No & 307 & 52.9 \\
Yes & 273 & 47.1 \\
Do you have a textbook for each subject you are doing? & \\
No & 199 & 30.0 \\
Yes & 465 & 70.0 \\
Are you shuffled in your school/classes? & \\
No & 497 & 75.6 \\
Yes & 160 & 24.4 \\
Do you get Awards if you have performed well academically? \\
No \\
Yes & 386 & \\
\hline
\end{tabular}

Table 2: Bivariate analysis of students/learners' performance

\begin{tabular}{|c|c|c|}
\hline Variables & $0 \%-49 \%$ & $50 \%-100 \%$ \\
\hline \multicolumn{3}{|c|}{ Does class size affects academic performance? } \\
\hline No & 198 & 152 \\
\hline Yes & 146 & 165 \\
\hline \multicolumn{3}{|c|}{$(p$-value $=0.028)$} \\
\hline \multicolumn{3}{|c|}{ Do you do Physics practicals in your school? } \\
\hline No & 95 & 131 \\
\hline Yes & 233 & 138 \\
\hline \multicolumn{3}{|c|}{$(p$-value $=0.000)$} \\
\hline \multicolumn{3}{|c|}{ Do you do Life science practicals in your school? } \\
\hline No & 143 & 164 \\
\hline Yes & 169 & 104 \\
\hline \multicolumn{3}{|c|}{$(p$-value $=0.209)$} \\
\hline \multicolumn{3}{|c|}{ Do you have a textbook for each subject you are doing? } \\
\hline No & 92 & 107 \\
\hline Yes & 252 & 213 \\
\hline \multicolumn{3}{|c|}{$(p$-value $=0.036)$} \\
\hline \multicolumn{3}{|c|}{ Are you shuffled in your school? } \\
\hline No & 242 & 255 \\
\hline Yes & 99 & 61 \\
\hline \multicolumn{3}{|c|}{$(p$-value $=0.002)$} \\
\hline \multicolumn{3}{|c|}{ Do you get awards in your school if you have performed well academically? } \\
\hline No & 129 & 143 \\
\hline $\begin{array}{l}\text { Yes } \\
(p \text {-value }=0.026)\end{array}$ & 214 & 172 \\
\hline
\end{tabular}


Table 3: Variables in the equation of students' performance- Logistic regression

\begin{tabular}{lllllll}
\hline Variables & B & SE & WALD & df & Sig & Exp(B) \\
\hline Size & -0.280 & 0.183 & 2.335 & 1 & 0.127 & 0.756 \\
Physics & 0.563 & 0.233 & 5.825 & 1 & $\mathbf{0 . 0 1 1}$ & 1.756 \\
Life Science & 0.271 & 0.216 & 1.576 & 1 & 0.209 & 1.312 \\
Textbook & 0.184 & 0.197 & 0.871 & 1 & $\mathbf{0 . 0 9 8}$ & 1.202 \\
Shuffle & 0.210 & 0.225 & 0.867 & 1 & $\mathbf{0 . 0 4 2}$ & 1.233 \\
Award & 0.309 & 0.185 & 2.793 & 1 & $\mathbf{0 . 0 2 8}$ & 1.362 \\
constant & -7.60 & 0.231 & 10.815 & 1 & 0.001 & 0.468 \\
\hline
\end{tabular}

Table 4: Pass rate of grade 12 learners for the 17 schools

\begin{tabular}{|c|c|c|}
\hline Year \& pass rate & Frequency & Percentage \\
\hline \multicolumn{3}{|l|}{2007} \\
\hline $0-49 \%$ & 6 & 35.3 \\
\hline $50-100 \%$ & 11 & 64.7 \\
\hline \multicolumn{3}{|l|}{2008} \\
\hline $0-49 \%$ & 3 & 17.6 \\
\hline $50-100 \%$ & 14 & 82.4 \\
\hline \multicolumn{3}{|l|}{2009} \\
\hline $0-49 \%$ & 5 & 29.4 \\
\hline $50-100 \%$ & 12 & 70.6 \\
\hline \multicolumn{3}{|l|}{2010} \\
\hline $0-49 \%$ & 5 & 29.4 \\
\hline $50-100 \%$ & 12 & 70.6 \\
\hline \multicolumn{2}{|c|}{ Table 5: Qualification of teachers/educators in the 17 schools } & Percentage \\
\hline \multicolumn{3}{|l|}{ Master's degree } \\
\hline Rarely & 14 & 82.4 \\
\hline Often & 3 & 17.6 \\
\hline \multicolumn{3}{|l|}{ Honours degree } \\
\hline Rarely & 15 & 88.2 \\
\hline Often & 2 & 11.8 \\
\hline \multicolumn{3}{|l|}{ Bachelor degree } \\
\hline Rarely & 4 & 23.5 \\
\hline Often & 13 & 76.5 \\
\hline \multicolumn{3}{|l|}{ Diplomas } \\
\hline Rarely & 6 & 35.3 \\
\hline Often & 11 & 64.7 \\
\hline \multicolumn{3}{|l|}{ Certificates } \\
\hline Rarely & 2 & 15.4 \\
\hline Often & 11 & 84.6 \\
\hline
\end{tabular}


Table 6: Regression analysis (OLS)

\begin{tabular}{llllll}
\hline Source & SS & df & MS & F & Sig \\
\hline Corrected Model & 59.583 & 5 & 11.917 & 6.406 & 0.000 \\
Intercept & 59.111 & 1 & 59.111 & 31.777 & $\mathbf{0 . 0 0 0}$ \\
Physics & 7.048 & 1 & 7.048 & 3.789 & $\mathbf{0 . 0 0 3}$ \\
Textbook & 6.471 & 1 & 6.471 & 3.479 & $\mathbf{0 . 0 6 3}$ \\
Shuffle & 16.023 & 1 & 16.023 & 8.614 & $\mathbf{0 . 0 5 2}$ \\
Awards & 6.303 & 1 & 6.303 & 3.388 & $\mathbf{0 . 0 4 6}$ \\
Class size & 1.984 & 1 & 1.984 & 1.067 & 0.302 \\
Life science & 3.771 & 1 & 3.771 & 2.052 & 0.153 \\
Error & 1043.552 & 561 & 1.860 & & \\
Total & 8321 & 567 & & & \\
Corrected Total & 1103.136 & & & & \\
\hline
\end{tabular}

Dependent variable: performance (pass rate of gr 12)

Table 6b: Coefficients of learners' performance

\begin{tabular}{llllll}
\hline Parameter & $\begin{array}{l}\text { B } \\
\text { (Unstandardized) }\end{array}$ & SE & $\begin{array}{l}\text { Beta } \\
\text { (standardized) }\end{array}$ & T & Sig \\
\hline Intercept & 2.052 & 0.364 & - & 5.637 & 0.000 \\
Physics & 0.248 & 0.128 & 0.254 & 1.947 & $\mathbf{0 . 0 0 3}$ \\
Textbook & 0.240 & 0.128 & 0.240 & 1.865 & $\mathbf{0 . 0 6 3}$ \\
Shuffle & 0.418 & 0.142 & 0.366 & 2.935 & $\mathbf{0 . 0 5 2}$ \\
Awards & 0.219 & 0.119 & 0.215 & 1.841 & $\mathbf{0 . 0 4 6}$ \\
Class size & -0.122 & 0.118 & -0.156 & -1.033 & 0.302 \\
Life science & 0.204 & 0.143 & 0.210 & 1.432 & 0.153 \\
\hline
\end{tabular}

Dependent variable: performance (pass rate of gr 12)

Table 7: ANOVA

\begin{tabular}{|c|c|c|c|c|c|}
\hline Model & $\begin{array}{l}\text { Sum } \\
\text { Squares }\end{array}$ & of $\mathrm{df}$ & MS & $F$ & Sig \\
\hline Regression & 7.753 & 6 & 1.292 & 5.454 & .000 \\
\hline Residual & 127.692 & 539 & .237 & & \\
\hline Total & 135.445 & 545 & & & \\
\hline
\end{tabular}

a. Predictors: (Constant), do you get awards if you have performed well? do you do practical in your school?, does the class size affect your academic performance?, do you have text books for each subject you are doing?, are you shuffled in your school?, do you do practical in your school?

b. Dependent Variable: what was the pass rate of Grade 12 in the following past years in your school

Table 1 show that $53 \%$ of the students reported that the class size does not affect their academic performance, $38.8 \%$ of students do not do Physics practical in their schools because there are no laboratories and $52.9 \%$ of the students do not do Life science practical. About $30.0 \%$ of the students do not have textbooks for each of their subjects and $43.1 \%$ do not get awards from their schools irrespective of how well they perform. Out of the $58.7 \%$ of the students who get awards from their schools, some get certificates, some get vouchers, some get study materials (stationary, dictionary, memory-stick (flash drive), etc.) and some get trophies. Other awards include: bursaries, educational fields' trip, school uniform, medals and money. All these awards are meant to motivate the students to keep on doing well because their good work is acknowledged and appreciated. Table 2 gives the results from the cross-tabulation. There is a very strong relationship between performance and availability of laboratories $(p$-value $=0.000)$. Similarly, there is a very strong relationship between performance and a text book ( $p$-value $=0.036)$; a strong association between performance and shuffling ( $p$-value $=0.002$ ), and a strong association between performance and giving of awards. Thus, if students are rewarded for their good performance, they get encouraged and motivated. Furthermore, there is a very strong relationship between performance and the class size ( $p$-value $=0.028)$, such that the larger the class size 
the lower the pass rate.

Table 3 gives the summary of the analysis by logistic regression. The results confirm that there is a strong association between Performance and the availability of laboratories for Physics practical, $p$-value $=0.011$. The logistic regression analysis has confirmed the following: that there is a strong relationship between performance and awards, ( $p$-value $=0.028$ ); performance and shuffling of students, $(p$-value $=0.042)$; but weak relationship between performance and textbooks, $(p$-value = 0.098). For the class size, the logistic regression analysis showed no relationship. Similarly there is no relationship between performance and the Life sciences, ( $p$-value $=0.209)$.

Mathematically, the model from the multiple logistic regression analysis, can be expressed as follows:

$\underline{\text { Log odd }}=-7.60+0.563$ science practical +0.309 awards +0.210 shuffle +0.184 textbooks

Implying that

$\underline{\text { Odd ratio (performance) }}=0.468+1.756$ science practical +1.362 awards +1.233 shuffle +1.202 textbooks.

The data were also transformed and; multiple regressions (OLS) and General Linear Modelling were also done as a further confirmation (http//www.ats.ucla.edu/stat/spss/dae/logit.htm; Menard, 1995:43; Hosmer and Lemeshow, 2000:50 - 56).

And the model from these analyses is as follows (see Tables $6 \& 6 \mathrm{~b}$ ):

$\underline{\text { Performance }}=2.0652+0.248$ science practical +0.24 textbooks +0.418 shuffling +0.219 awards(unstandardized)

$\underline{\text { Performance }}=0.254$ science practical +0.24 textbooks +0.366 shuffling +0.215 awards (standardized) .

Table 5 gives the distribution of qualifications of teachers in the sampled schools. Teachers with master's degree were $4.6 \%$; honors degree $6.9 \%$; bachelor's degree $30.0 \%$; diploma $25.4 \%$ and a teaching certificate $33.1 \%$. Almost $60 \%$ of the high school teachers do not have bachelor's degrees. Most teachers have only a teaching certificate as a qualification.

Discussion: The pass rate for grade 12 in this district, according to this survey, is about $70 \%$ (see Table 4) which is commendable since Vhembe is predominantly rural with a high degree of poverty. Many high schools in the district lack good educational infrastructure such as: laboratories, classrooms, more qualified, committed and dedicated staff, textbooks, etc., which promote good performance by students. In 2012 for example, there were some schools in the Limpopo province which did not receive their textbooks until September when the academic year was almost ending. This action prompted a non-governmental organisation (NGO) called, Section 27, to take the Minister of the Department of Basic Education to court for various infractions, including: slow delivery of textbooks, non-provision of other resources needed for quality education, lack of commitment to education, and lack of concern for students' plight (Sunday Times newspaper 1 July 2012, p.5 review).

Education reflects the broad social, economic and political structure of the country it serves. In South Africa, the past education system for blacks was closely related to the broad development programme and political injustices. Poverty is concentrated in provinces that have a high rural population, which is predominantly Black. Their high poverty is due to their high illiteracy and unemployment levels. These perpetuate the problems that influence poor school performance by the children. Mji and Makgato (2006:259) cite five areas, namely: Teaching strategies; Content knowledge and understanding; Motivation and interest; Laboratory usage; and non-completion of syllabus as direct factors influencing poor performance in high schools. As mentioned earlier, the new government came with a key mechanism to redress the inequality in schools through the distribution of education budget policy that provided the framework for allocating "nonpersonnel recurrent costs of the basis of need." But it appears the redress formula has not worked 
successfully till now. Research investigations on reasons why students do not do well are important because they help to identify the problems that need to be resolved. Some students complain that teachers at high schools are less friendly, always intimidating students with quizzes and competitions, and consequently making students feel less academically prepared. The ensuing fear makes their level of performance drops.

\section{Conclusion}

From the logistic regression analysis, the explanatory variables for performance are availability of laboratories for science practical, shuffling of students, and recognising and giving awards to hardworking students, which are true at a significance level of 5\%; while providing textbooks to students also contributes to poor performance marginally at the $10 \%$ level. From Table $6 \mathrm{~b}$, the coefficient for the class size is negative $(b=-0.122$ for the unstandardized) and/or beta $(\beta=-0.156$ for the standardized) confirming that a large class has a negative effect on good performance. Unfortunately the $p$-value shows that the class size has no statistical significance on performance in this instance. In short, the factors affecting the performance of students in high schools in the Vhembe district of the Limpopo province in this study are: availability of laboratories for science practical, shuffling of students in class, giving out awards to good students who excel in their studies and provision of textbooks. Large class size results in overcrowding, making some students inactive, uncontrollable, and some students hiding behind others. Large classes disturb concentration and individual attention for students is also not possible in large classes.

Recommendations: It is believed that this study has provided vital information about how awards or incentive can motivate students to strive for excellence; how much infrastructure available in public schools can contribute to good academic excellence. It has revealed in part the extent to which the attitude to work by both staff and students contribute to success rate. Stakeholders for school administration in Vhembe can look at some of the following recommendations and plan accordingly. This study recommends to the School Management Team and the Department of Education the following: To ensure that teachers identify underperforming students, put them together in one class, (say, class C), and give them extra lessons after hours. Students' support teams should also be formed to help students that may need individual help or extra lessons. Teachers are to be encouraged to give some awards to deserving and hardworking students as motivations and appreciations for their good performance, and that: the governing authority and/or government should endeavour to provide laboratories for practical for relevant (science) subjects. The governing authority and/or government should provide textbooks to schools, especially schools in rural areas; and in good time, immediately when academic year begins, so that serious academic work can start right from the beginning of the year.

\section{References}

Ardens, F. (2010). Teachers Shortages? The need for more reliable information at school level. Review of Education, Skills Development and Innovation. (RESDI, 1-3); Pretoria: HSRC Press.

Cameron, L. (2009). Higher grade- Dinaledi schools initiative helps boost maths, science pass rates. Engineering news, 29(31), 1-104.

Einhorn, E. (2008). City short of science teachers. Accessed on 7 October 2008 at [http://www.nydaiynews.com/nylocal/education/2008/04/15/2008-04-15cityshortof.

Fonseca, J. M. B. \& Conboy, J. E. (2006). Secondary student perceptions of factors affecting failure in science in Portugal. Eurasia Journal of Mathematics, Science and Technology Education, 2(2), 82-95.

Grant, M. \& Hallman, K. (2006). Pregnancy-related School Dropout and Prior School Performance in South Africa. The Population Council. New York: Population Council. 32pp.

Hosmer, D. W. \& Lemeshow, S. (2000). Applied Logistic Regression, $2^{\text {nd }}$ Edition. New Jersey: Wiley.

Howe, S. J. (2003). Language and other background factors affecting secondary pupils' performance in Mathematics in South Africa. African Journal of Research in SMT Education, 7, 1-20.

Kyei, K. A. \& Nemaorani, T. M. (2014). Establishing Factors that affect performance of grade ten students in high schools: A case study of the Vhembe district in South Africa. Journal of Emerging Trends in Educational Research and Policy Studies (JETERAPS), 5(7), 83-87.

Larose, D. T. (2006). Data Mining: Methods and Models. New Jersey: John Wiley \& Sons. 
Madibeng, T. (2006). Engineering education in SA- a failure or success? RACA Journal, 21(11). Accessed on 12 August 2008 at [http://www.plumbingafrica.co.za/r\&afeb2006education.htm].

Makgato, M. (2007). Factors associated with poor performance of learners in mathematics and physical science in secondary schools in Soshanguve: South Africa. Educational Research, 4(1), 89-103.

McGrath, S. (2010). Public Further Education and Training (FET) Colleges under New Departmental Structures: What Challenges remain for 2010 and beyond? RESDI, 1 - 3; Pretoria: HSRC.

Menard, S. (1995). Applied Logistic Regression Analysis. London: Sage Publications.

Mji, A. \& Makgato, M. (2006). Factors associated with high school learner's poor performance: a spotlight on Mathematics and Physical Science. South African Journal of Education, 26(2), 253-266.

Munn, N. L. (1996). The evolution and growth of human behaviour. London: Harrap.

Muwanga-Zake, J. W. F. (2008). Is science education in a crisis? Some problems in South Africa. Science Education. Accessed on 19 March 2008 at [http://www.scienceinafrica.co.za/scicrisis.htm].

Muzah, P. (2011). An exploration into the school related factors that causes high matriculation failure rates in physical science in public high schools of Alexandra Township. Unpublished M.Ed dissertation. University of South Africa (UNISA). Pretoria: UNISA.

Ruby, A. (2006). Improving science achievement at high- poverty urban middle schools. USA: Wiley Periodicals. Inc.78.

Saiduddin, J. (2003). Factors affecting Achievement at Junior High School on the Pine Ridge Reservation. Spain: Ohio State University.

Themane, M. J. (1989). Thirty years of Black education (1953-1983) with Special Emphasis on Aims. A Historical Education Appraisal. Dissertation submitted to the University of the North. Sovenga: Limpopo Province.

UN Convention Rights of the Child.(http//www:unicef.org/southafrica;accessed on 12/07/2011).

Van Der Berg, S. \& Louw, M. (2006). Educational attainment and intergenerational social mobility in South Africa. HSRC Working Papers 09/2006.

\section{$\underline{\text { Notes }}$}

- Academic is used to describe any exercise that is related to work done in schools, colleges and universities, especially work which involves studying and reasoning rather than practical or technical skills (Collins Advanced Dictionary of English,2009).

- A performance is how successful someone is and how well they do something (Collins Advanced Dictionary, 2009).

- Academic performance refers to how learners/students deal with their studies and how they cope with or accomplish different tasks given to them by their teachers or lecturers.

Academic knowledge brings a person in and ahead of the competitive world and on the surface, someone who is performing well academically is related to the following:

- The ability to study and remember facts, this is something to do with recalling things studied.

- The ability to see how facts fit together and form larger patterns knowledge, this is called constructivism; the ability to come up with new ideas from previous known information with the newly learned ideas.

- The ability to think in relation to facts, and

- The ability to communicate your knowledge verbally or down on a paper.

Good academic performance is linked to having good organisational skills. 